\title{
School Performance Measurement Based on Business Architecture
}

\author{
Idzni Shabrina*, Rista Prahastina**, Fifit Yulianti Amanah H.***, Muhammad Ainul Yaqin**** \\ Informatics Engineering Departement, Faculty of Science and Technology, Universitas Islam Negeri (UIN) Maulana Malik Ibrahim \\ Jl. Gajayana No.50, Dinoyo, Kec. Lowokwaru, Kota Malang, Jawa Timur 65144 - Indonesia. \\ Email: 16650017@student.uin-malang.ac.id*,16650006@student.uin-malang.ac.id**, \\ 16650018@ student.uin-malang.ac.id***, yaqinov@ti.uin-malang.ac.id****
}

\begin{abstract}
School performance measurement is the process of collecting, processing, analyzing and interpreting data about the quality of work carried out by school members in carrying out their main tasks and roles. Measuring the performance of an organization will encourage the achievement of objectives in the organization. A performance measurement system must be built so that the information obtained is as much and as accurate as possible. Business architecture is a formal representation and tools as well as information for business professionals in assessing, changing and designing a business. Business modeling will show the relationship of organizational behavior with the information needed, and the relationships that occur within the organizational structure, so that business architecture is the main thing that must be completely defined before continuing on to the next stage. To encourage schools to achieve goals and design business strategies that are in line with the objectives, this research will propose a system for measuring school performance based on business architecture.
\end{abstract}

Keywords: School Performance Measurement, Business Architecture, SNP, Process Model, Management Project.

Abbreviations: SNP (Standar Nasional Pendidikan).

\section{INTRODUCTION}

School performance measurement is the process of collecting, processing, analyzing and interpreting data about the quality of work carried out by school members (especially service providers) in carrying out their main tasks and roles. To conduct a school performance measurement a number of indicators are needed. Indicators are measures to determine the performance of a person, program or institution as a whole (IEES, 1986: 40). Thus, school performance indicators are a measure to determine the performance of a school institution (Ikhfan, 2016).

School performance is the achievement of schools resulting from the process/school behavior. In conclusion, the essence of school performance is the success achieved by schools as measured by indicators to improve the learning process in achieving learning objectives, namely learning outcomes (Muttaqin, 2010: 2).

In a performance measurement there are several aspects that can be measured. According to Nurkolis (2003), performance can be measured by effectiveness, quality, productivity, efficiency, innovation, quality of life and work morale. Meanwhile, according to Fenwick (2008) using three aspects, namely economy, efficiency and effectiveness. Economics is for the comparison of costs and quality of resources. Efficiency as a comparison of resources used.

While the effectiveness of knowing the extent to which objectives are achieved according to targets. The description above shows that there are several aspects that can be used in measuring a performance. According to Haryoto (2008) in the process of measuring a performance must be returned to the goals and reasons for the formation of the organization itself.

In a dynamic, more open and competitive environment, it has implications for change and progress very rapidly and quickly. The education sector is one sector that receives the impact of change and is required to always adapt to change (responsive adaptative). Responding to changes that occur, schools, as an important part of the education sector are required to remain consistent and concerned about maintaining the quality of all activities carried out. One strategy to remain committed in maintaining quality is to measure performance that has been achieved in a systematic and measurable and accountable manner (Haris, 2016: 10).

Measuring organizational performance is very important. Measurement of organizational performance according to Bastian (2001: 330) will encourage the achievement of organizational goals and will provide feedback for continuous improvement efforts. Therefore the performance measurement system must be built in such a way that information about performance can be obtained as much and as accurately as possible (Haris, 2016: 11).

Business architecture is a formal representation and tools and information for business professionals in measuring, changing and designing a business (SOA, 2010). Architectural conceptual modeling in enterprise architecture is influenced by 3 (three) main layers, namely the business layer, application layer and technology layer (Jonkers, et al, 2004). Business layer 
describe 3 (three) aspects, namely structure, behavior and information. These three aspects are very important in business modeling, business modeling shows the relationship of organizational behavior with the information needed, and the relationships that occur within the organizational structure, so that business architecture is the main thing that must be defined in full before proceeding to the next stages. According to Ralph Whittle and Conrad Myrick (2004), business architecture in an enterprise can be connected with all the components that exist in the development of enterprise architecture.

Table 1. Related research.

\begin{tabular}{|c|c|c|c|}
\hline No & Author and title & Measurement Parameters & Measurement technique \\
\hline 1 & $\begin{array}{l}\text { Emi Susanti } \\
\text { "Analisis Kinerja Dengan Pendekatan Balanced } \\
\text { Scorecard Di SMAN } 3 \text { Yogyakarta" }\end{array}$ & $\begin{array}{l}\text { Specific Factors: } \\
\text { 1. Personal / Individual Factors. } \\
\text { 2. Leadership factors. } \\
\text { 3. System factors. } \\
\text { 4. Contextual / situational factors. } \\
\text { - SNP }\end{array}$ & Balanced Scorecard \\
\hline 2 & $\begin{array}{l}\text { Aditya Ramadhan } \\
\text { "Penilaian Standar Pengelolaan Dalam Sistem } \\
\text { Informasi Supervisi, Monitoring dan Evaluasi pada } \\
\text { Sekolah Standar Nasional (SSN) Tingkat SLTP" }\end{array}$ & Standar Pengelolaan & SNP \\
\hline 3 & $\begin{array}{l}\text { Alexander Malik Hidayatullah } \\
\text { "Penilaian Standar Isi Dalam Sistem Informasi } \\
\text { Supervisi, Monitoring dan Evaluasi pada Sekolah } \\
\text { Standar Nasional (SSN) Tingkat SLTP" }\end{array}$ & Standar Isi & SNP \\
\hline
\end{tabular}

Based on previous studies, researchers only measure school performance based on SNP alone, none of which are based on business architecture. This is what drives the author to build a framework for measuring school performance based on business architecture.

\section{Related Research}

In a study entitled "Analisis Kinerja Dengan Pendekatan Balanced Scorecard Di SMAN 3 Yogyakarta" compiled by Emi Susanti stated that the use of the Balanced Scorecard method in school measurements showed good overall results from various aspects. In the financial aspects of measurement using the concept of value for money shows good performance with the results of the acquisition is very economical, effective and quite efficient. Whereas in other aspects such as customer aspects, internal business processes and learning and growth showed good performance results.

In a study entitled "Penilaian Standar Pengelolaan Dalam Sistem Informasi Supervisi, Monitoring Dan Evaluasi Pada Sekolah Standar Nasional (SSN) Tingkat SLTP" by Aditya Ramadhan explained the measurement automation of an information system used to measure the achievement of good school management processes according to the criteria of management of Standar Sekolah Nasional (SSN) in education authorities of Gresik disctrict. In this study, it was concluded that $95.4 \%$ of the test items were successful and valid, so the application could be run according to the standar proses SSN.

Whereas in the study entitled "Otomasi Penilaian Standar Isi Dalam Sistem Informasi Supervisi, Monitoring Dan Evaluasi Pada Sekolah Standar Nasional (SSN) Tingkat SLTP" by Alexander Malik Hidayatullah explained the researchers were trying to create an information system to facilitate the implementation of Supervision, Monitoring and Evaluation of the Content Standards with the hope that the existing standard values can be quickly identified. It was concluded that $89 \%$ of the test items were successful and valid. So the application can be run according to SSN instruments.

\section{RESEARCH METHODOLOGY}

\section{Study Area}

The object of this research is a school. Every school has a business process in it. Every business process is covered according to established standards.

\section{Procedure}

The following are the steps used in measuring performance based on existing business processes:

\section{Identification of Business Architecture}

Business architecture is a business concept or design in which there are business processes that play an important 
role in system design. Business processes that occur in schools, described in the process models. Here are some business processes in schools based on SNP that are illustrated by the process model.

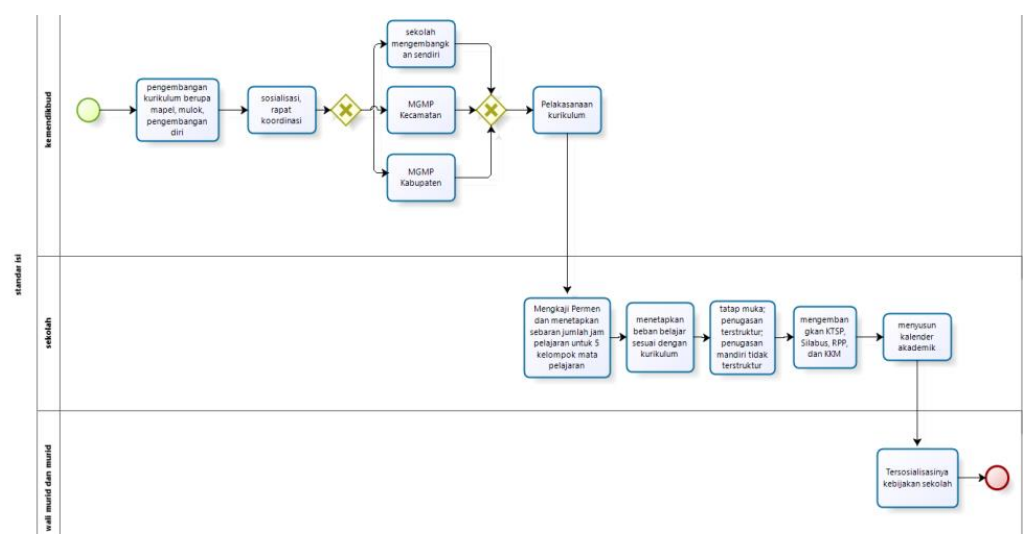

Figure 1. Process models based on standar isi.

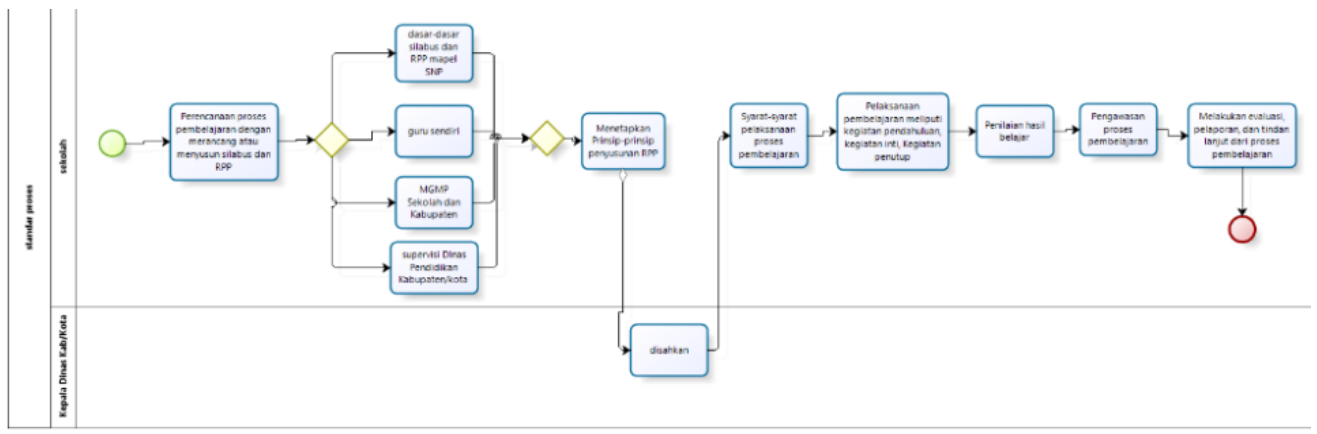

Figure 2. Process models based on standar proses.

\section{School Business Process Identification}

Existing business processes are then divided based on time, ie day, week, month, semester and year. These business processes must be carried out according to certain rules.

The following are the first principles for measuring business process performance:

1. If the business process is successfully carried out 76$100 \%$ of the target set, the business process performance measurement score is 4

2 . If the business process is successfully carried out 51$75 \%$ of the target set, the business process performance measurement score is 3 .

3 . If the business process is successfully carried out 26$50 \%$ of the target set, the business process performance measurement score is 2 .

4. If the business process carried out is only successful $<26 \%$ of the specified target, the business process performance measurement score is 1 .

And also proposed a different rule, the second rule as follows:
1. If the business process is $100 \%$ successful or reaches the specified target, the business process performance measurement score is 4

2. If the business process does not reach the specified target or $<100 \%$, the business process performance measurement score is 0 .

Standards of achieving business processes are adjusted to the standards in the SNP. The following are tables of the division of business processes based on time and aspects measured.

Table 2. Standards and aspects used in measuring daily school performance.

\begin{tabular}{|c|c|c|}
\hline SNP & Code & Aspect \\
\hline $\begin{array}{l}\text { Standar } \\
\text { Penilaian }\end{array}$ & PBD1 & Student achievement KD \\
\hline Standar Proses & PBD2 & $\begin{array}{l}\text { Requirements for implementing } \\
\text { the learning process }\end{array}$ \\
\hline & PBD3 & Implementation of learning \\
\hline
\end{tabular}

PBD: Daily Business Process 
Table 3. Standards and aspects used in measuring weekly school performance.

\begin{tabular}{lll}
\hline SNP & Code & Aspect \\
\hline Standar Isi & PBW1 & Student study time \\
& PBW2 & Structured assignment \\
Standar Proses & PBW3 & Teacher workload \\
\hline
\end{tabular}

PBW: Weekly Business Processes

Table 4. Standards and aspects used in measuring monthly school performance.

\begin{tabular}{lll}
\hline SNP & Code & Aspect \\
\hline Standar & PBM1 & SPP Payment \\
Pembiayaan & PBM2 & Educator salary \\
& PBM3 & Education staff salary \\
& PBM4 & Learning Activities \\
& PBM5 & Student activities \\
& PBM6 & School stationery \\
& PBM7 & Consumable tools \\
& PBM8 & Consumables materials \\
& PBM9 & Transport and official travel \\
& PBM10 & Duplicating exam sheets \\
& PBM11 & Power and services \\
& PBM12 & Indirect educational operational \\
& & activities \\
\hline
\end{tabular}

PBM: Monthly Business Process

Table 5. Standards and aspects used in measuring semester school performance.

\begin{tabular}{|c|c|c|}
\hline SNP & Kode & Aspek \\
\hline \multirow[t]{4}{*}{ Standar Isi } & PBS1 & Curriculum content \\
\hline & PBS2 & Curriculum structure \\
\hline & PBS3 & $\begin{array}{l}\text { Kriteria Ketuntasan Minimal } \\
\text { (KKM) }\end{array}$ \\
\hline & PBS4 & $\begin{array}{l}\text { Time allocation of the } \\
\text { education calendar }\end{array}$ \\
\hline \multirow{10}{*}{$\begin{array}{l}\text { Standar } \\
\text { Kompetensi } \\
\text { Lulusan } \\
\text { Standar } \\
\text { Pembiayaan }\end{array}$} & PBS5 & Intelligence \\
\hline & & \\
\hline & & \\
\hline & PBS6 & Meeting activities \\
\hline & PBS7 & Duplicating exam sheets \\
\hline & PBS8 & Subject syllabus information \\
\hline & PBS9 & $\begin{array}{l}\text { The number of subject } \\
\text { syllabus information that } \\
\text { being informed }\end{array}$ \\
\hline & PBS10 & $\begin{array}{l}\text { Reporting the results of the } \\
\text { assessment at the end of the } \\
\text { semester }\end{array}$ \\
\hline & PBS11 & Coordination evaluation \\
\hline & PBS12 & $\begin{array}{l}\text { Reporting the results of } \\
\text { assessment of subjects }\end{array}$ \\
\hline Standar & PBS13 & Physical and spiritual health \\
\hline $\begin{array}{l}\text { Pendidikan dan } \\
\text { Tenaga } \\
\text { Kependidikan }\end{array}$ & PBS14 & $\begin{array}{l}\text { The ability to plan, learning } \\
\text { in accordance with the } \\
\text { principles of learning }\end{array}$ \\
\hline
\end{tabular}

PBS: Semester Business Process
Table 6. Standards and aspects used in measuring annual school performance.

\begin{tabular}{|c|c|c|}
\hline SNP & Code & Aspect \\
\hline \multirow{3}{*}{$\begin{array}{l}\text { Standar } \\
\text { Pengelolaan }\end{array}$} & PBY1 & School goals \\
\hline & PBY2 & School work plan \\
\hline & PBY3 & $\begin{array}{l}\text { Implementation of school } \\
\text { activities Implementation of } \\
\text { school activities in accordance } \\
\text { with the annual work plan. }\end{array}$ \\
\hline \multirow{10}{*}{$\begin{array}{l}\text { Standar } \\
\text { Pembiayaan } \\
\text { Standar } \\
\text { Kompetensi } \\
\text { Lulusan } \\
\text { Standar } \\
\text { Pendidikan dan } \\
\text { Tenaga } \\
\text { Kependidikan }\end{array}$} & PBY4 & Facilities and infrastructure \\
\hline & PBY5 & Further education \\
\hline & PBY6 & $\begin{array}{l}\text { Meeting the number of special } \\
\text { service personnel. }\end{array}$ \\
\hline & PBY7 & Academic Qualifications \\
\hline & PBY8 & $\begin{array}{l}\text { Suitability of educational } \\
\text { background }\end{array}$ \\
\hline & PBY9 & Mastery of subject matter \\
\hline & PBY10 & Research competence \\
\hline & PBY11 & Minimum special qualifications \\
\hline & PBY12 & $\begin{array}{l}\text { Surat Keputusan (SK) as the } \\
\text { principal }\end{array}$ \\
\hline & PBY13 & Leadership ability \\
\hline \multirow{5}{*}{$\begin{array}{l}\text { Standar Sarana } \\
\text { dan Prasarana }\end{array}$} & PBY14 & Completeness of infrastructure \\
\hline & PBY15 & Classroom \\
\hline & PBY16 & Health \\
\hline & PBY17 & Worship place \\
\hline & PBY18 & Playground / sports \\
\hline
\end{tabular}

PBY: Annual Business Process

\section{Data Analysis}

After measuring business processes in accordance with aspects of the SNP, the results of the assessment are then processed again based on the time of the business process, so the following formulas are obtained.

The formula for measuring daily school performance is as follows:

$$
\mathrm{D}=\frac{\sum_{i=1}^{n} P B D_{i}}{A D_{n} \times 4}
$$

D : daily school performance measurement function PBD : daily business process score

$\mathrm{AD}_{\mathrm{n}} \quad$ : many aspects of daily measurement

The following is the formula for measuring weekly school performance:

$$
\mathrm{W}=\frac{\left(\frac{\sum_{i=1}^{n} P B W_{i}}{A W_{n} \times 4}\right)+\left(\frac{\sum_{i=1}^{n} D_{i}}{D_{n}}\right)}{2}
$$

$\mathrm{W}$ : weekly school performance measurement function PBW : weekly business process scores

AWn : many aspects of weekly measurement

D : daily performance measurement

Dn : number of days with $\mathrm{Dn} \leq 6$ 
The formula for measuring monthly school performance is as follows:

$$
\mathbf{M}=\frac{\left(\frac{\sum_{i=1}^{n} P B M_{i}}{A M_{n} \times 4}\right)+\left(\frac{\sum_{i=1}^{n} W_{i}}{W_{n}}\right)}{2}
$$

M : monthly school performance measurement function PBM : monthly business process score

$\mathrm{AM}_{\mathrm{n}}$ : many aspects of monthly measurement

$\mathrm{W}$ : weekly performance measurement

$\mathrm{W}_{\mathrm{n}}$ : the number of weeks with $\mathrm{Wn} \leq 4$

The formula for measuring semester school performance is as follows:

$$
\mathrm{S}=\frac{\left(\frac{\sum_{i=1}^{n} P B S_{i}}{A S_{n} \times 4}\right)+\left(\frac{\sum_{i=1}^{n} M_{i}}{M_{n}}\right)}{2}
$$

S : school performance measurement function in one semester

PBS : business process scores in one semester

$\mathrm{AS}_{\mathrm{n}} \quad$ : many aspects of semester measurement

M : monthly performance measurement

$\mathrm{M}_{\mathrm{n}} \quad$ : number of months with $\mathrm{Mn} \leq 6$

The formula for measuring weekly school performance is as follows:

$$
\mathrm{Y}=\frac{\left(\frac{\sum_{i=1}^{n} P B Y_{i}}{A Y_{n} \times 4}\right)+\left(\frac{\sum_{i=1}^{n} S_{i}}{S_{n}}\right)}{2}
$$

$\mathrm{Y}$ : annual school performance measurement function PBY : annual business process score

$\mathrm{AY}_{\mathrm{n}}$ : many aspects of annual measurement

$S \quad$ : semester performance measurement

$\mathrm{Sn} \quad$ : the number of semesters with $\mathrm{Sn} \leq 2$

The ranking of school performance based on business architecture is as follows.

1. Rank A (Very Good) if the school scores from 0.86 to $1(0.86<\mathrm{Y}<1)$.

2. Rank B (Good) if the school gets a value of 0.71 to $0.85(0.71<\mathrm{Y}<0.85)$.

3. Rank C (Good Enough) if the school gets a value of 0.56 to $0.7(0.56<\mathrm{Y}<0.7)$.

4. Rank D (Poor) if the school scores less than 0.56 (Y $<0.56)$.

\section{RESULT AND DISCUSSION}

\section{Result I}

Results I are carried out by following the first principle.Suppose a school has a daily business process score as follows:

\begin{tabular}{|c|c|c|}
\hline $\mathrm{PBD}_{1}$ & $\mathrm{PBD}_{2}$ & $\mathrm{PBD}_{3}$ \\
\hline 2 & 4 & 3 \\
\hline
\end{tabular}

So the calculation of the school's daily school performance is as follows:

$$
\mathrm{D}=\frac{2+4+3}{3 \times 4}=0,75
$$

And suppose the school has conducted a business process for a week with $D_{n}=6$ and the results of the calculation of school performance every day are as follows:

\begin{tabular}{|l|l|l|l|l|l|}
\hline $\mathrm{D}_{1}$ & $\mathrm{D}_{2}$ & $\mathrm{D}_{3}$ & $\mathrm{D}_{4}$ & $\mathrm{D}_{5}$ & $\mathrm{D}_{6}$ \\
\hline 0,75 & 0,83 & 0,75 & 0,92 & 0,67 & 0,58 \\
\hline
\end{tabular}

And the weekly business process score is as follows:

\begin{tabular}{|c|c|c|}
\hline $\mathrm{PBW}_{1}$ & $\mathrm{PBW}_{2}$ & $\mathrm{PBW}_{3}$ \\
\hline 3 & 4 & 4 \\
\hline
\end{tabular}

So we get the value:

$$
\mathrm{W}=\frac{\frac{3+4+4}{3 \times 4}+\frac{0,75+0,83+0,75+0,92+0,67+0,58}{6}}{2}=\frac{0,92+0,75}{2}=\frac{1,67}{2}=0,83
$$

And suppose the school has conducted a business process for one month of work with $\mathrm{W}_{\mathrm{n}}=4$ and the results of the calculation of school performance every week are as follows:

\begin{tabular}{|l|l|l|l|}
\hline $\mathrm{W}_{1}$ & $\mathrm{~W}_{2}$ & $\mathrm{~W}_{3}$ & $\mathrm{~W}_{4}$ \\
\hline 0,83 & 0,78 & 0,87 & 0,8 \\
\hline
\end{tabular}

And the monthly business process score is as follows:

\begin{tabular}{|c|c|c|c|c|c|c|c|c|c|c|c|}
\hline $\mathrm{P}$ & $\mathrm{P}$ & $\mathrm{P}$ & $\mathrm{P}$ & $\mathrm{P}$ & $\mathrm{P}$ & $\mathrm{P}$ & $\mathrm{P}$ & $\mathrm{P}$ & $\mathrm{P}$ & $\mathrm{P}$ & $\mathrm{P}$ \\
$\mathrm{B}$ & $\mathrm{B}$ & $\mathrm{B}$ & $\mathrm{B}$ & $\mathrm{B}$ & $\mathrm{B}$ & $\mathrm{B}$ & $\mathrm{B}$ & $\mathrm{B}$ & $\mathrm{B}$ & $\mathrm{B}$ & $\mathrm{B}$ \\
$\mathrm{W}$ & $\mathrm{W}$ & $\mathrm{W}$ & $\mathrm{W}$ & $\mathrm{W}$ & $\mathrm{W}$ & $\mathrm{W}$ & $\mathrm{W}$ & $\mathrm{W}$ & $\mathrm{W}$ & $\mathrm{W}$ & $\mathrm{W}$ \\
1 & 2 & 3 & 4 & 5 & 6 & 7 & 8 & 9 & 10 & 11 & 12 \\
\hline 3 & 3 & 4 & 2 & 3 & 4 & 4 & 3 & 4 & 3 & 3 & 3 \\
\hline
\end{tabular}

So we get the value: 
$\mathrm{M}=$

$3+3+4+2+3+4+4+3+4+3+3+3 \quad 0,83+0,78+0,87+0,8$

$\frac{\frac{3+3+4+2+3+4+4+3+4+3+3+3}{12 \times 4}+\frac{0,83+0,78+0,87+0,8}{4}}{2}=\frac{0,81+0,82}{2}=\frac{1,63}{2}=0,82$

And suppose the school has conducted a business process for one semester with $M_{n}=6$ and the results of the calculation of school performance each month are as follows:

\begin{tabular}{|l|l|l|l|l|l|}
\hline $\mathrm{M}_{1}$ & $\mathrm{M}_{2}$ & $\mathrm{M}_{3}$ & $\mathrm{M}_{4}$ & $\mathrm{M}_{5}$ & $\mathrm{M}_{6}$ \\
\hline 0,82 & 0,78 & 0,82 & 0,81 & 0,81 & 0,83 \\
\hline
\end{tabular}

And the semester business process scores are as follows:

\begin{tabular}{|c|c|c|c|c|c|c|c|c|c|c|c|c|c|}
\hline P & P & P & P & P & P & P & P & P & P & P & P & P & P \\
B & B & B & B & B & B & B & B & B & B & B & B & B & B \\
S & S & S & S & S & S & S & S & S & S & S & S & S & S \\
1 & 2 & 3 & 4 & 5 & 6 & 7 & 8 & 9 & 10 & 11 & 12 & 13 & 14 \\
\hline 2 & 3 & 4 & 4 & 3 & 2 & 3 & 3 & 4 & 4 & 3 & 3 & 2 & 3 \\
\hline
\end{tabular}

So we get the value:

$$
\mathrm{S}=\frac{\frac{2+3+4+4+3+2+3+3+4+4+3+3+2+3}{14 \times 4}+\frac{0,82+0,78+0,82+0,81+0,81+0,83}{6}}{2}=\frac{0,77+0,81}{2}=\frac{1,58}{2}=0,79
$$

And suppose the school has conducted a business process for one year with $S_{n}=2$ and the results of the calculation of school performance each semester are as follows:

\begin{tabular}{|c|c|}
\hline $\mathrm{S}_{1}$ & $\mathrm{~S}_{2}$ \\
\hline 0,79 & 0,76 \\
\hline
\end{tabular}

And the semester business process scores are as follows:

\begin{tabular}{|c|c|c|c|c|c|c|c|c|c|c|c|c|}
\hline $\mathrm{P}$ & $P$ & $\mathrm{P}$ & $P$ & $P$ & $\mathrm{P}$ & $\mathrm{P}$ & $P$ & $P$ & $\mathrm{P}$ & $P$ & $P$ & $P$ \\
\hline B & B & B & B & B & B & B & B & B & B & B & B & B \\
\hline $\mathrm{Y}$ & $Y$ & $\mathrm{Y}$ & $Y$ & Y & Y & $\mathrm{Y}$ & $Y$ & $\mathrm{Y}$ & Y & $\mathrm{Y}$ & $\mathrm{Y}$ & $Y$ \\
\hline 1 & 2 & 3 & 4 & 5 & 6 & 7 & 8 & 9 & 10 & 11 & 12 & 13 \\
\hline 3 & 3 & 4 & 2 & 3 & 2 & 3 & 3 & 4 & 4 & 3 & 3 & 2 \\
\hline $\mathrm{P}$ & $\mathrm{P}$ & $\mathrm{P}$ & $\mathrm{P}$ & $\mathrm{P}$ & & & & & & & & \\
\hline B & B & B & B & B & & & & & & & & \\
\hline $\mathrm{Y}$ & $Y$ & $\mathrm{Y}$ & $Y$ & $Y$ & & & & & & & & \\
\hline 14 & 15 & 16 & 17 & 18 & & & & & & & & \\
\hline 3 & 4 & 4 & 3 & 2 & & & & & & & & \\
\hline
\end{tabular}

So we get the value:

$\mathrm{Y}=\frac{\frac{3+3+4+2+3+2+3+3+4+4+3+3+2+3+4+4+3+2}{18 \times 4}+\frac{0,79+0,76}{2}}{2}=\frac{0,76+0,78}{2}=\frac{1,54}{2}=0,77$

\section{Result II}

Result II follows the second principle in the same case so the following values are obtained.
The score of the school's daily business process is as follows:

\begin{tabular}{|c|c|c|}
\hline $\mathrm{PBD}_{1}$ & $\mathrm{PBD}_{2}$ & $\mathrm{PBD}_{3}$ \\
\hline 0 & 4 & 0 \\
\hline
\end{tabular}

So the calculation of the school's daily school performance is as follows:

$\mathrm{D}=\frac{4}{3 \times 4}=0,33$

The business process for one work week with $D_{n}=6$ and the results of the calculation of school performance every day is as follows:

\begin{tabular}{|l|l|l|l|l|l|}
\hline $\mathrm{D}_{1}$ & $\mathrm{D}_{2}$ & $\mathrm{D}_{3}$ & $\mathrm{D}_{4}$ & $\mathrm{D}_{5}$ & $\mathrm{D}_{6}$ \\
\hline 0,3 & 0,3 & 0 & 0,67 & 0 & 0 \\
\hline
\end{tabular}

And the weekly business process scores are as follows:

\begin{tabular}{|l|l|l|}
\hline $\mathrm{PBW}_{1}$ & $\mathrm{PBW}_{2}$ & $\mathrm{PBW}_{3}$ \\
\hline 0 & 4 & 4 \\
\hline
\end{tabular}

So we get the value:

$\mathrm{W}=\frac{\frac{4+4}{3 \times 4}+\frac{0,3+0,3+0,67}{6}}{2}=\frac{0,67+0,21}{2}=\frac{0,88}{2}=0,44$

The school has conducted business processes for one month of work with $\mathrm{W}_{\mathrm{n}}=4$ and the results of the calculation of school performance every week are as follows:

\begin{tabular}{|l|l|l|l|}
\hline $\mathrm{W}_{1}$ & $\mathrm{~W}_{2}$ & $\mathrm{~W}_{3}$ & $\mathrm{~W}_{4}$ \\
\hline 0,44 & 0,19 & 0,58 & 0,51 \\
\hline
\end{tabular}

And the monthly business process scores are as follows:

\begin{tabular}{|c|c|c|c|c|c|c|c|c|c|c|c|}
\hline $\mathrm{P}$ & $\mathrm{P}$ & $\mathrm{P}$ & $\mathrm{P}$ & $\mathrm{P}$ & $\mathrm{P}$ & $\mathrm{P}$ & $\mathrm{P}$ & $\mathrm{P}$ & $\mathrm{P}$ & $\mathrm{P}$ & $\mathrm{P}$ \\
$\mathrm{B}$ & $\mathrm{B}$ & $\mathrm{B}$ & $\mathrm{B}$ & $\mathrm{B}$ & $\mathrm{B}$ & $\mathrm{B}$ & $\mathrm{B}$ & $\mathrm{B}$ & $\mathrm{B}$ & $\mathrm{B}$ & $\mathrm{B}$ \\
$\mathrm{W}$ & $\mathrm{W}$ & $\mathrm{W}$ & $\mathrm{W}$ & $\mathrm{W}$ & $\mathrm{W}$ & $\mathrm{W}$ & $\mathrm{W}$ & $\mathrm{W}$ & $\mathrm{W}$ & $\mathrm{W}$ & $\mathrm{W}$ \\
1 & 2 & 3 & 4 & 5 & 6 & 7 & 8 & 9 & 10 & 11 & 12 \\
\hline 0 & 0 & 4 & 0 & 0 & 4 & 4 & 0 & 4 & 0 & 0 & 0 \\
\hline
\end{tabular}

So we get the value:

$\mathrm{M}=$

$\frac{\frac{4+4+4+4}{12 \times 4}+\frac{0,44+0,19+0,58+0,51}{4}}{2}=\frac{0,33+0,43}{2}=\frac{0,76}{2}=0,38$

And the school has conducted a business process for one semester with $M_{n}=6$ and the results of the 
calculation of school performance each month are as follows:

\begin{tabular}{|l|l|l|l|l|l|}
\hline $\mathrm{M}_{1}$ & $\mathrm{M}_{2}$ & $\mathrm{M}_{3}$ & $\mathrm{M}_{4}$ & $\mathrm{M}_{5}$ & $\mathrm{M}_{6}$ \\
\hline 0,38 & 0,29 & 0,4 & 0,33 & 0,34 & 0,38 \\
\hline
\end{tabular}

And the semester business process scores are as follows:

\begin{tabular}{|c|c|c|c|c|c|c|c|c|c|c|c|c|c|}
\hline P & P & P & P & P & P & P & P & P & P & P & P & P & P \\
B & B & B & B & B & B & B & B & B & B & B & B & B & B \\
S & S & S & S & S & S & S & S & S & S & S & S & S & S \\
1 & 2 & 3 & 4 & 5 & 6 & 7 & 8 & 9 & 10 & 11 & 12 & 13 & 14 \\
\hline 0 & 0 & 4 & 4 & 0 & 0 & 0 & 0 & 4 & 4 & 0 & 0 & 0 & 0 \\
\hline
\end{tabular}

So we get the value:

$$
\mathrm{S}=\frac{\frac{4+4+4+4}{14 \times 4}+\frac{0,38+0,29+0,4+0,33+0,34+0,38}{6}}{2}=\frac{0,29+0,35}{2}=\frac{0,64}{2}=0,32
$$

And the school has been doing business processes for one year with $\mathrm{Sn}=2$ and the results of the calculation of school performance each semester are as follows:

\begin{tabular}{|c|c|}
\hline $\mathrm{S}_{1}$ & $\mathrm{~S}_{2}$ \\
\hline 0,32 & 0,29 \\
\hline
\end{tabular}

\begin{tabular}{|c|c|c|c|c|c|c|c|c|c|c|c|c|}
\hline $\mathrm{P}$ & $P$ & $P$ & $P$ & $P$ & $P$ & $\mathrm{P}$ & $P$ & $P$ & $P$ & $P$ & $\mathrm{P}$ & $\mathrm{P}$ \\
\hline B & B & B & B & B & B & B & B & B & B & B & B & B \\
\hline$Y$ & Y & Y & $\mathrm{Y}$ & Y & Y & Y & Y & $Y$ & Y & Y & Y & Y \\
\hline 1 & 2 & 3 & 4 & 5 & 6 & 7 & 8 & 9 & 10 & 11 & 12 & 13 \\
\hline 0 & 0 & 4 & 0 & 0 & 0 & 0 & 0 & 4 & 4 & 0 & 0 & 0 \\
\hline $\mathrm{P}$ & $\mathrm{P}$ & $\mathrm{P}$ & $\mathrm{P}$ & $\mathrm{P}$ & & & & & & & & \\
\hline B & B & B & B & B & & & & & & & & \\
\hline $\mathrm{Y}$ & Y & Y & $Y$ & $Y$ & & & & & & & & \\
\hline 14 & 15 & 16 & 17 & 18 & & & & & & & & \\
\hline 0 & 4 & 4 & 0 & 0 & & & & & & & & \\
\hline
\end{tabular}

And the semester business process scores are as follows:

So we get the value:

$$
\mathrm{Y}=\frac{\frac{4+4+4+4+4}{18 \times 4}+\frac{0,32+0,29}{2}}{2}=\frac{0,28+0,31}{2}=\frac{0,58}{2}=0,29
$$

\section{Discussion}

Calculation of school performance measurement using the first principle obtained daily performance values $\mathrm{D}=$ 0.75 and weekly performance values $\mathrm{W}=0.83$ and monthly performance values $\mathrm{M}=0.82$ and semester performance values $S=0.79$ and annual performance values $\mathrm{Y}=0,77$ so that the school is in the range of $0.71<\mathrm{Y}<0.85$, which is ranked $\mathrm{B}$ or good. While the calculation of school performance measurement using the second principle obtained daily performance values $\mathrm{D}=0.33$ and weekly performance values $\mathrm{W}=0.44$ and monthly performance values $\mathrm{M}=0.38$ and semester performance values $\mathrm{S}=0.32$ and annual performance values $\mathrm{Y}=0.29$ so that the school is in the range of $\mathrm{Y}$ $<0.51$ which is ranked D or poor. Both show different results. This is due to the first principle that still tolerates business processes that have not been completed perfectly while in the second rule business processes will only be counted if the business process is completed.

\section{CONCLUSION}

From the results of measuring school performance with the proposed method, several conclusions can be drawn, including:

1. The results of school performance measurement based on business architecture can interpret data about the quality of work performed by school residents within a certain time.

2. The results of measuring school performance based on business architecture using the two proposed rules show different results. Performance measurement using the first rule yields a value of $\mathrm{Y}=0.77$ indicating the school has a rating of $\mathrm{B}$ or good. While the performance measurement using the second rule yields a value of $\mathrm{Y}=0.29$ which indicates that the school has a D or poor rating. School performance assessment based on business architecture depends on how to calculate existing business processes.

\section{ACKNOWLEDGEMENTS}

Thanks to Mr. Muhammad AinulYaqin for his guidance in doing this research. And also for friends and teams who participated in the work on this research.

\section{REFERENCES}

Agency for International Development, Bureau for Science and Technology Office Education (1986). Improving the efficiency of educational systems (IEES): the evaluation of efficiency in educational development activities. Florida: Educational Efficiency Clearinghouse.

Bastian, Indra. 2001. Akuntansi Sektor Publik. BPFE, Yogyakarta. Haryoto. (2008). Kinerja Organisasi. Granesia. Bandung.

Hidayatullah, AM. 2015. Otomasi Penilaian Standar Isi dalam Sistem Informasi Supervisi, Monitoring dan Evaluasi pada Sekolah Standar Nasional (SSN) Tingkat SLTP. [Thesis]. Maulana Malik Ibrahim State Islamic University, Malang. [Indonesian].

Haris, Ikhfan. 2016. Indeks Kinerja Sekolah Konsep Dan Aplikasi Pengukuran Kemandirian Mutu Dan Inovasi Pengelolaan Sekolah. Samudra Biru, Yogyakarta

Jonkers, H., et al, 2004, Concept for Modeling Enterprise Architecture, International Journal of Cooperative Information System, Vol. 13(3), pp. 257-287.

Muhammad, Fadel. (2008). Reinventing Local Government: Pengalaman dari Daerah. Elex Media Komputindo. Jakarta. 
Nurkolis. (2003). Manajemen Berbasis Sekolah: Teori, Model, dan Aplikasi. Grasindo. Jakarta.

Ramadhan, Aditya. 2016. Penilaian Standar Pengelolaan dalam Sistem Informasi Supervisi, Monitoring, dan Evaluasi pada Sekolah Standar Nasional (SSN) Tingkat SLTP. [Thesis]. Maulana Malik Ibrahim State Islamic University, Malang. [Indonesian].

SOA. 2010. Business Architecture: The Missing Link between Business Strategy and Enterprise Architecture, SOA Consortium Members Present, Object Management Group (OMG).

Sudrajat, Akhmad. 2010. Instrumen Supervisi dan Kinerja Sekolah
SNP.https://akhmadsudrajat.wordpress.com/2010/09/22/instru men-supervisi-dan-kinerja-sekolah-berdasarkan-snp/commentpage-7/.

Suhardiman. 2012. Studi Pengembangan Kepala Sekolah Konsep dan Aplikasi. PT. Rineka Cipta. Jakarta.

Susanti, Emi.2017. Analisa Kinerja Dengan Pendekatan Balanced Scorecard di SMA N 3 Yogyakarta. PGRI Yogyakarta University

Whittle, Ralph and Myrick, Conrad. 2004. Enterprise Business Architecture: The Formal Link between Strategy and Results, Auerbach Publications. CRC Press. USA. 